\title{
TÉRSZERKEZET AZ EURÓPAI UNIÓBAN
}

\author{
(Regional Structures in the European Union)
}

\section{SZABÓ PÁL}

A három világgazdasági pólus közül az európai kontinens tizenöt tagállamát tömörítő Európai Unió regionális társadalmi-gazdasági sokszínúsége közismert, amit szemuigyre vehetünk az egyediség irányából, a regionális földrajz szemüvegén keresztül (Probáld 1994), de közelíthetünk a regionális tudomány oldaláról is, keresve a térszerkezet átfogóbb jellemzőit, generalizáltabb jegyeit. Ez utóbbi kört leszúkítve a gazdasági fejlettség térbeli szerkezetére olyan tézisek kerülnek elötérbe, mint az észak-dél ellentét, a centrum-periféria modell, illetve ez utóbbi ,gyümölcsösebb” verziója, a megszulletése óta vitatott „kék banán” (Brunet 1989). E tanulmány célja, hogy ezeket a téziseket a regionális tényadatok tükrében alátámassza vagy vitassa, valamint a fejlettség klasszikus mutatóján (egy före eső GDP) túl más - a fejlettséget tükröző vagy éppenséggel tőle „idegen” - tényezők térbeliségét is vizsgálja.

Területi felosztásnak az EU NUTS 2 szintjét vettük, ami esetünkben számszerüleg 199 egységet jelent, miután a vizsgált térbỏl kizártuk a négy francia, két portugál és egy spanyol tengerentúli tartományt. Ennek a közigazgatási felosztásnak ismert és jogos kritikája, hogy mind a népesség, mind a terület szempontjából nagy a szóródás (87 ill. $132 \%$ a relatív szórás).

A következő térparamétereket vizsgáltuk:

- földrajzi helyzet, mely a kitüntetett földrajzi irányt, makroregionális tagozódást,

- gazdasági centrumtól való távolság, mely a centrum-periféria viszonyt,

- szomszédsági hatás, mely a lokális szerveződést, egymásra hatást mutatja (Nemes Nagy 1993).

A földrajzi helyzet azonosítása során egy régiót egy ponttal reprezentáltunk: vagy a régió székhelyét vagy ennek hiányában legnépesebb városát és annak földrajzi koordinátáit vettük, oly módon hogy a tengelyek irányának észak-délt és keletnyugatot, az origónak pedig a pontok koordinátáinak számtani átlagát választottuk (1. ábra). A távolság paraméternél a gazdasági centrumtól való légvonalbeli távolságot vettük, gazdasági centrumnak a meglévő koordináta pontok GDP-vel súlyozott átlagát, a gazdasági súlypontot jelöltủk ki (ez a franciaországi Metztől 115 km-re dél-délkeletre esik). A szomszédsági hatásnál a szomszédos régiók adatainak átlagát számoltuk ki (a GDP-t kivéve súlyozatlanul), de a szomszédság megállapításánál egyszerüsítve csak a szomszédság tényét vettük figyelembe, eltekintve a régióhatárok hosszától (Nemes Nagy 1998). A mediterrán-tengeri szigeteknél (7 régió) vagy a tengeren húzódó regionális határok alapján jelöltük ki a szomszédokat, vagy ha más ország régiója közelebb volt, akkor szomszédnak ezt, valamint az anyaország legközelebbi régióját vettük. 


\section{1. ÁBRA}

$A z E U$ regionális ponttérképe

(Regional Point-Map of the EU)

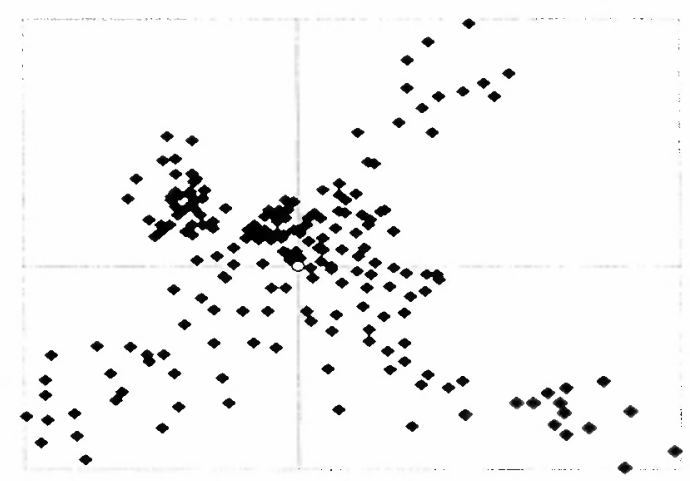

Forrás: Saját szerkesztés.

A következő mutatók térbeliségét vizsgáltuk: egy före eső GDP (vásárlóerő paritáson), aktivitási ráta, munkanélküliségi ráta, foglalkozási szerkezet - mezőgazdaságban, iparban, szolgáltatásban dolgozók aránya. Az adatok az 1995. és az 1996. évekre vonatkoznak.

Módszerként a többváltozós lineáris regresszióanalízist (backward eliminációs regresszió) választottuk, mely alkalmas a bonyolultabb térszerkezeti struktúrák kimutatására is. A valóságos térszerveződés nem mindig egyértelmü, a térképek alapján nehezen megállapítható térbeli szervezỏdés viszont ezzel a módszerrel feltárható (Nemes Nagy 1993).

A fejlettséget az egy före eső GDP-vel reprezentáljuk, de kérdésként merült fel, hogy vajon a többi mutató szintén tükrözi-e a fejlettséget. A korrelációs egyủithatók (1. táblázat) azt mutatják, hogy még a legalkalmasabb mutató - a mezőgazdaságban dolgozók aránya - is csak közepesen erős korrelációs kapcsolatot mutat az egy före eső GDP-vel. Ez azt is jelenti, hogy a térbeli szervezỏdés e két mutató esetén mutathat szorosabb kapcsolatot. (A korrelációs táblázatot mátrixszá bỏvítve kiderül, hogy a mutatók egyéb kombinációi sem adnak ennél - abszolút értékben - nagyobb együtthatót).

\section{TÁBLÁZAT}

A GDP/fö és a többi mutatószám régiószintü korrelációja az EU-ban (199 egység) (Correlation of the GDP/Capita and Other Indicators on a Regional Level in the EU)

\begin{tabular}{cccccc}
\hline $\begin{array}{c}\text { Aktivitási } \\
\text { ráta } \\
(\%)\end{array}$ & $\begin{array}{c}\text { Munkanél- } \\
\text { küliségi ráta } \\
(\%)\end{array}$ & $\begin{array}{c}\text { Mezögazdaságban } \\
\text { dolgozók aránya } \\
(\%)\end{array}$ & $\begin{array}{c}\text { Iparban } \\
\text { dolgozók } \\
\text { aránya }(\%)\end{array}$ & $\begin{array}{c}\text { Szolgáltatásban } \\
\text { dolgozók } \\
\text { aránya }(\%)\end{array}$ \\
\hline GDP/fö & 0,27 & $-0,41$ & $-0,54$ & 0,13 & 0,39 \\
\hline
\end{tabular}

Forrás: Saját számítás. 
A vizsgált mutatók területi differenciáltságát a relatív szórás (V) tükrében vizsgálva (2. táblázat) megállapítható, hogy a mezögazdaságban dolgozók aránya esetén legnagyobb a szóródás. Az EU régiói közül 16-nál 1\% alatti értékekkel találkozunk, mely térségek részben nagyvárosok ill. nagyvárosi régiók (pl. Bréma, Berlin, Nagy-London, Île de France) valamint angol régiók. Emellett 13 olyan görög és spanyol térség is fellelhetö, ahol $20 \%$ feletti értékek a jellemzőek. Magas a szórás a munkanélküliség esetén is, a dél-olasz és spanyol tartományok $20 \%$ feletti értékeivel szemben az 5\% alatti - nagyobbrészt - osztrák és német tartományok állnak. Kiegyenlített képet mutat az aktivitási ráta és a szolgáltatásban dolgozók aránya, míg az iparban dolgozók aránya és az egy före eső GDP közepes szórásértékekkel jellemezhetö.

\section{TÁBLÁZAT}

A regresszióelemzés eredményei

(Results of the Regression Analysis)

\begin{tabular}{|c|c|c|c|c|c|c|}
\hline & GDP/fö & $\begin{array}{l}\text { Aktivitási } \\
\text { ráta }\end{array}$ & $\begin{array}{l}\text { Munkanél- } \\
\text { küliségi } \\
\text { ráta }\end{array}$ & $\begin{array}{l}\text { Mezőgazda- } \\
\text { ságban dol- } \\
\text { gozók aránya }\end{array}$ & $\begin{array}{c}\text { Iparban } \\
\text { dolgozók } \\
\text { aránya }\end{array}$ & $\begin{array}{l}\text { Szolgálta- } \\
\text { tásban } \\
\text { dolgozók } \\
\text { aránya }\end{array}$ \\
\hline $\mathrm{V}(\%)$ & 27 & 11 & 54 & 112 & 24 & 14 \\
\hline $\mathrm{R}^{2}(\%)$ & 36 & 79 & 64 & 62 & 52 & 43 \\
\hline \multirow[t]{4}{*}{$B(\%)$} & $\operatorname{SZOM}(37)$ & $\operatorname{SZOM}(89)$ & $\operatorname{SZOM}(80)$ & $\operatorname{SZOM}(40)$ & $\operatorname{SZOM}(72)$ & $\operatorname{SZOM}(65)$ \\
\hline & TÁV(-20) & & & $\hat{E}-D(-22)$ & & \\
\hline & É-D(15) & & & TÁV(21) & & \\
\hline & & & & $\mathrm{Ny}-\mathrm{K}(18)$ & & \\
\hline
\end{tabular}

Forrás: Sajất számítás.

A regresszió által kapott jelzöszámok közül az $\mathrm{R}^{2}$ a szignifikáns magyarázó változók együttes determinációs együtthatója, amely megmutatja az explicit térparaméterek szerepét az adott jelenség területi differenciáltságában, a magyarázó változók $B$ paraméterének nagysága (abszolút értékben) pedig az egyes térváltozók magyarázó erejére mutat rá.

A térbeliség szerepét mérö regressziós modell négy térváltozójának összesített magyarázó ereje $\left(\mathrm{R}^{2}\right)$ az aktivitási, a munkanélküliségi ráták, valamint a mezögazdaságban dolgozók aránya esetén a legnagyobb (2. táblázat). Csekélyebb magyarázó erejủ a térbeliség az iparban és a szolgáltatásban dolgozók aránya illetve a fejlettségi mutató esetén. Azonban míg a hat mutató közül négynél a szomszédsági hatás az egyedüli térszerkezeti jegy ( $(B)$, addig kettőnél összetettebb a kép: habár ezeknél szintén a szomszédság a legerösebb, mégis szignifikánsak egyéb térfaktorok is. A mezőgazdaságban dolgozók arányánál mind a négy tényezö szerepe kimutatható, míg a fejlettségnél három, mivel a nyugat-kelet irány nem játszik szerepet.

A fejlettségnél maradva, a bevezetőben említett tézisek - észak-dél, centrum-periféria - visszaköszönnek a modellből. A gazdasági centrumtól vett távolság, valamint az észak-déli helyzet szerepét hủen adják vissza a $\beta$ értékek. A kettő azonban egymást nem kizárva, hanem együttesen jelentkezik. Azonban ki kell hangsúlyozni, hogy ezeknél erősebb magyarázó erỏvel bír a szomszédsági hatás, vagyis általános- 
ságban igaz, hogy fejlett térségnek fejlett, míg fejletlennek fejletlen a szomszédja. Ennek térbeli irányultságára pedig egy észak-dél irányba kissé torzult centrumperiféria szerkezet allítható. Mélyebbre ásva vizsgálhatjuk egyesével is a térparamétereket (3. táblázat).

\section{TÁBLÁZAT}

Korrelációs együtthatók a vizsgált térfaktorokkal

(Correlation Coefficients with the Examined Space Factors)

\begin{tabular}{ccccc}
\hline & Észak-Dél & Kelet-Nyugat & $\begin{array}{c}\text { Gazdasági centrumtól } \\
\text { való távolság }\end{array}$ & $\begin{array}{c}\text { Szomszédos régiók } \\
\text { átlaga (GDP/fó) }\end{array}$ \\
\hline GDP/fó & 0,34 & $-0,02$ & $-0,48$ & 0,56 \\
\hline
\end{tabular}

Forrás: Saját számítás.

A korrelációs együtthatók a fenti eredményeket támasztják alá, de értékük nem olyan magas, mint várnánk. Ez azt mutatja, hogy a térbeliség szerepe ebböl a megközelítésből nem olyan tézisszerủ, mint szeretnénk, a regionális fejlettség területi sokszinüsége nehezen modellezhetó.

A centrum-periféria modell azonban él, erösebb, mint az észak-dél dualizmus, és ezt alá támaszthatjuk két nem lineáris regresszió segítségével is (2., 3. ábra). A két polinomiális regresszió korrelációs hányadosai $\left(R^{2}\right)$ magasabbak, mintha egyváltozós lineáris regressziót állítanánk, és ezek korrelációs hányadosait vennénk, azaz a lenti trendvonalak jobban kirajzolják a földrajzi pozíciók szerinti térbeli tagozódást. Mindkét görbe (fordított parabola) az EU centrum-periféria modelljét tükrözi vissza. A pontokra illeszthetö trendvonal parabolikus jellege ad arra is magyarázatot, hogy miért esett ki a backward eliminációs regressziónál a nyugat-kelet reláció. Ezen térbeli irány szerinti szerkezet még szabályosabb is, mint az észak-dél reláció, amit a keleti (Görögország, a volt NDK, több finn tartomány), valamint a nyugati (Ibériai-félsziget) „,végek” elmaradottsága magyaráz. Az észak-dél pozíció szerinti térszerkezetnél gyengébb a centrum-periféria modell, mivel a fejletlen görög, spanyol, portugál és dél-olasz régiók kissé elhúzzák a görbe szárát déli irányba.

\section{2. ÁBRA}

Regionális fejlettség az nyugat-kelet koordináta függvényében az EU-ban (Regional Advancement in the Function of the West-East Co-ordinates in the EU)

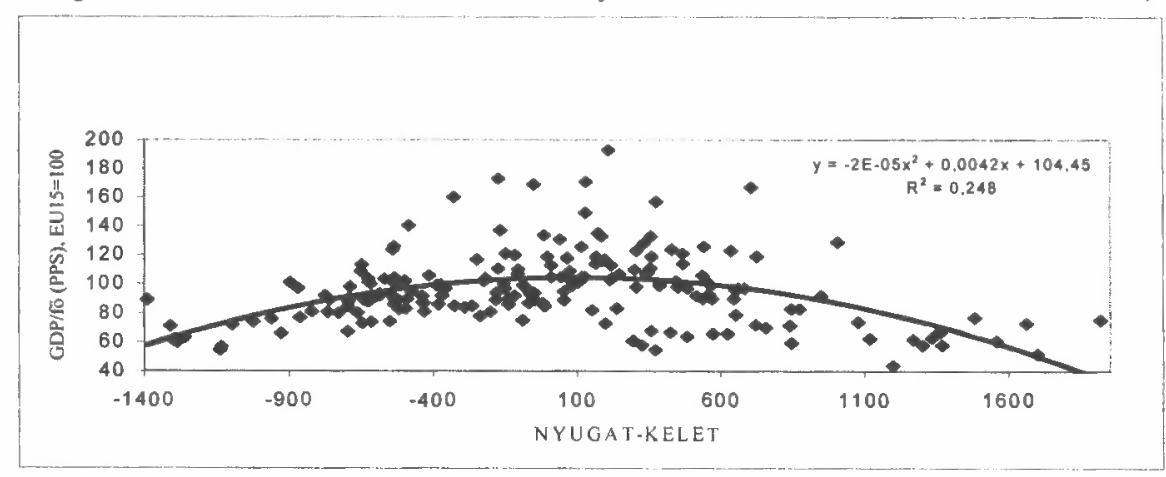

Forrás: Saját szerkesztés. 


\section{3. ÁBRA}

Regionális fejlettség az észak-dél koordináta függvényében az EU-ban (Regional Advancement in the Function of the North-South Co-ordinates in the EU)

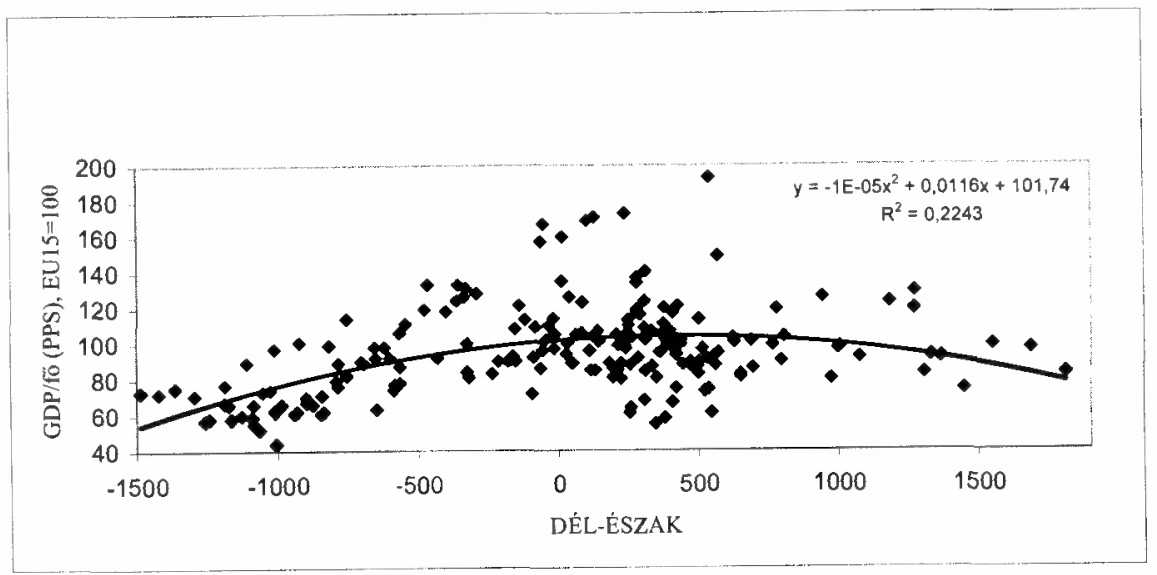

Forrás: Saját szerkesztés.

A vizsgálatba bevont többi mutatónál, mint kiderült, a szomszédsági hatás a legerősebb. A mezőgazdaságban dolgozók arányánál, mivel több térfaktor is szignifikánsnak minösül, érdemes egyesével is „mérni” a kapcsolatot (4. táblázat).

\section{TÁBLÁZAT}

Korrelációs együtthatók a vizsgált térfaktorokkal (Correlation Coefficients with the Examined Space Factors)

\begin{tabular}{ccccc} 
& Észak-Dél & Kelet-Nyugat & $\begin{array}{c}\text { Gazdasági centrum- } \\
\text { tól való távolság }\end{array}$ & $\begin{array}{c}\text { Szomszédos } \\
\text { régiók átlaga } \\
\text { (GDP/fö) }\end{array}$ \\
\hline $\begin{array}{c}\text { Mezógazdaságban } \\
\text { dolgozók aránya }\end{array}$ & $-0,54$ & 0,39 & 0,60 & 0,75 \\
\hline
\end{tabular}

Forrás: Saját számítás.

Ennél a mutatónál - a szomszédságon kívül - a gazdasági centrumtól való távolság (centrum-periféria), valamint az észak-dél térszerveződés rajzolódik ki, ami még szabályosabb térszerkezetet mutat, mint az egy fỏre eső GDP-nél.

A többi jelzöszám esetében a regressziós modellben a szomszédsági hatás erỏteljessége miatt a többi térfaktor eltűnik, de ezek szerepe egy kivétellel nem is jelentős, a korrelációs együtthatók is alacsony értékeket adnak. Az egyetlen kivétel az aktivitási ráta és az észak-dél paraméter közötti szoros kapcsolat $(r=0,70)$ : a déleurópai országokban alacsonyabb a népesség aktivitása, amit a nöknek - a társadalmi tradíciókból eredóen - a munkaerőpiacon való csekélyebb részvételével magyarázhatunk. A mutatóknál ezzel a modellel meg nem rajzolható térszerkezet az EU regionális sokszinűségének ékes bizonyitéka. Ez azonban nem a mozaikszerüségben mutatkozik meg, hiszen a szomszédsági hatás erős. A munkanélküliség esetén a térbeli szerkezetet élrontja például, hogy mind északon (Finnország), mind 
délen (Spanyolország, Dél-Olaszország), mind a centrumban (Észak-Franciaország) találunk magas munkanélküliséggel küszködő régiókat, és mellettük alacsony rátával rendelkeznek a peremen fekvő görögországi, portugál régiók vagy a centrumban fekvő német tartományok. Az iparban illetve a szolgáltatásban dolgozók arányánál sem rajzolódik ki markáns területi tagolódás, ami jól tükrözi egyrészt azt, hogy a fejlettséggel gyengén korreláló mutatókról van szó (pl. Olaszországban a klasszikus észak-dél reláció nem mutatkozik meg a szolgáltatásban dolgozók arányát vizsgálva, mivel délen az alacsonyabb, északon pedig a magasabb értéktermelö szolgáltatási ágakban dolgozók egy kalapba kerülnek), másrészt mindkét ágazatnál a lokalitás szerepe (pl. ipari térségek, nagyvárosok, turizmus által érintett térségek) a döntő. Az alacsony ipari foglalkoztatottságú térségek között találunk elmaradott görög, spanyol és dél-olasz régiókat, de olyan fejlett vagy centrumközeli vagy perifériális helyzetủ nagyvárosi térségeket is, mint Brüsszel, Nagy-London, Utrecht, Stockholm. A sor másik végén a német dominanciát spanyol, olasz régiók törik meg. A szolgáltatást nézve szintén vegyes a kép, mivel az alacsony értékkel rendelkező görög és spanyol régiók között osztrák és német tartományok, a magas értékkel bíró, fejlett nagyvárosi térségek között pedig elmaradottabb, szórtan elhelyezkedó spanyol, belga és francia régiók lelhetök fel.

A kimutatott erős szomszédsági hatás miatt érdemes a területi autokorrelációt is vizsgálni. Az EU-ban átlagosan közel négy szomszédja van egy régiónak (maximum: Kasztília és Leon - 11 szomszéd, minimum: Berlin, Bécs, Írország, ÉszakÍrország, Cornwall-Devon, Szicília, Uusimaa(SF), Ceuta és Melilla - 1 szomszéd). A szomszédsági kapcsolatok feltárása új értéket csak két mutatónál (GDP/fö, mezőgazdaságban dolgozók aránya) jelent, mivel a többváltozós lineáris regresszió B értéke annál a négy mutatónál, ahol csak a szomszédsági hatás, mint egyedüli térfaktor maradt meg, megegyezik a területi autokorreláció értékeivel (5. táblázat). Ismételten ki kell emelni, hogy lényeges eleme az EU térszerkezetének a szomszédsági egymásrahatás, hasonulás. Ez leggyengébben a fejlettség esetén mutatkozik, mivel itt olyan „„örésvonalakat" lelhetünk fel, mint az Ancona-fal Olaszországban vagy „Nyugat-” és „Kelet-Németország” határvonala, valamint olyan, a környezetükből kiemelkedő szigeteket, mint a NUTS 2 szinten megjelenő nagyvárosok (Berlin, Brüsszel, Hamburg, Bréma, Bécs) illetve nagyvárosi régiók (Île de France, Nagy-London, Madrid). Más mutatók esetén is ki lehet emelni egyrészt szerkezeti vonalakat, melyek egyes esetekben országhatárokat rajzolnak ki (pl. a munkanélküliség drasztikus megváltozása a spanyol-portugál vagy a francia-olasz határon), más esetekben országhatáron belüli vízválasztók (pl. Olaszország, Németország), másrészt - mutatótól fủggỏen - magaslati vagy mélységi pontokat, amelyek leggyakrabban az elöbb említett, nagyvárosokhoz köthetö régiókat jelentik. A regionális léptékben kidomborodott szomszédsági relációk azonban elrejtik a kisebb egységek lokális mozaikszerűségét vagy éppenséggel hasonulását. 


\begin{tabular}{|c|c|c|c|c|c|c|}
\hline \multicolumn{7}{|c|}{$\begin{array}{c}\text { 5. TÁBLÁZAT } \\
\text { A területi autokorreláció értékei } \\
\text { (Values of Regional Autocorrelation) }\end{array}$} \\
\hline & GDP/fö & $\begin{array}{l}\text { Aktivitási } \\
\text { ráta }\end{array}$ & $\begin{array}{l}\text { Munka- } \\
\text { nélküli- } \\
\text { ségi ráta }\end{array}$ & $\begin{array}{l}\text { Mezőgazdaság- } \\
\text { ban dolgozók } \\
\text { aránya }\end{array}$ & $\begin{array}{l}\text { Iparban } \\
\text { dolgozók } \\
\text { aránya }\end{array}$ & $\begin{array}{l}\text { Szolgáltatás- } \\
\text { ban dolgozók } \\
\text { aránya }\end{array}$ \\
\hline $\begin{array}{c}\text { Területi } \\
\text { autokorreláció } \\
\text { értékei }\end{array}$ & 0,55 & 0,89 & 0,80 & 0,75 & 0,72 & 0,65 \\
\hline
\end{tabular}

Forrás: Saját szåmítás.

A feltárt térszerkezeti modellek esetén nem szabad megfeledkeznünk arról, hogy a területi felosztás közigazgatási szempontból elfogadható, de a pontok száma nem arányos, mivel míg Németország és Nagy-Britannia „túlreprezentált” (38 ill. 35 pont), addig terület és népesség szempontjából is „alulreprezentált” hozzájuk képest például Spanyolország vagy Olaszország. A pontok eloszlása pedig erőteljes sủrüsödést mutat a klasszikus centrumtérségben.

Szintén nem szabad megfeledkeznünk arról, hogy a vizsgált tér csak az EU-ra terjed ki, kizárva így mind a nyugat-, mind a kelet-közép-európai nem EU tagállamokat, régiókat. Ezek „bekapcsolása” a meglévö térszerkezetet egyes szegmenseiben megváltoztathatják, különösen ez utóbbi országoknak a modellbe való beléptetése rendezheti át a teret.

A fenti eredmények regionális politikai vonzataként meg kell említeni, hogy az EU szintjén jelenleg fỏ probléma a fejlett centrum - elmaradott periféria reláció. A magterülettöl minden irányba távol eső régiók felzárkóztatásának továbbra is egyik fő akadálya a földrajzi távolság. Ennek makroregionális színesítő eleme a délre billenés, vagyis a déli régiók fokozottabb elmaradottsága. Ez a probléma új irányt igazából akkor fog felvenni, ha a tagjelölt kelet-közép-európai országok is bekerülnek az EU terébe, mivel így jelentősen megnő, ha nem dominánssá válik a nyugatkelet reláció, és a jelenlegi „domborulat” keletről meredek lejtővel fog kiegészülni (hipotézis). Másik fontos jelzése az eredményeknek, hogy a differenciáltság regionális egyedisége mellett számolni kell az átmeneti térségekkel is, vagyis az erős szomszédsági hatás miatt nem lehet csak egy-egy térségre leszorítani a területi beavatkozást, hanem a probléma gócpontjától távolodva arányosan csökkenő mértékben be kell avatkozni a szomszédos térségek területi folyamataiba is.

A regionális közelítési mód fokozódása szükséges, mert ha sikerül megszabadulnunk az országhatárokkal tarkított, fejünkben élő Európa térképtől, akkor elénk tárul a jövő, a „régiók Európája”, ahol a fentebb kirajzolódott térszerkezetek, kiemelkedő térparaméterek kerülnek a középpontba, túllépve az országhatárok egyre halványuló szerepén. 


\section{Irodalom}

Brunet, R. (ed.) (1989) Les villes europeenes. Paris, Reclus/Datar.

Probáld F. (szerk.) (1994) Európa regionális földrajza. Budapest, Nemzeti Tankönyvkiadó.

Nemes Nagy J. (1993) Adalékok a térbeliség társadalmi magyarázó erejéhez (lokalitás, regionalizmus, centrum-periféria). Társadalmi-területi egyenlötlenségek Magyarországon. - Enyedi Gy. (szerk.), Budapest, Közgazdasági és jogi Könyvkiadó.

Nemes Nagy J. (1998) A tér a társadalomkutatásban. Budapest, Hilscher Rezső Szociálpolitikai Egyesület.

\section{REGIONAL STRUCTURES IN THE EUROPEAN UNION}

\section{PÁL SZABÓ}

In this study we try to show the regional structures of the EU based on regional data. The objects of the research were social-economic indices (GDP per capita, unemployment rate, activity rate and employment by economic sectors (percentage in total employment)) of NUTS 2 regions of the EU, and we examined the elements of the regional structure: NorthSouth, West-East, centre-periphery and neighbourhood. The method used was a linear regression (backward). The results show the most significant element is the neighbourhood, and out of the four indices this is the only one element of regional structure. The regional structure of the GDP per capita has three elements: neighbourhood, centre-periphery and North-South. The regressions (figures 2., 3.: West-East and South-North - GDP per capita) show the centre-periphery model. The research supports that the fact the issue of centre-periphery is a big problem in the $\mathrm{EU}$ in the regional policy, and the neighbourhood contacts of the regions is worth much more attention. 